\title{
Consequencias futuras da therapeutica
}

\author{
Pelo Dr. Rubião Meira, Lente Cathe= \\ dratico de Clinica Medica da Facul= \\ dade de Medicina e Cirurgia de São \\ Paulo.
}

Quem estudar, com detida attenção, as conquistas da therapeutica moderna e se aprofundar nas consequencias della, não pode deixar de reconhecer a somma grande de beneficios que ella tem espalhado, enchendo de salutares effeitos a raça humana, cortando uma serie enorme de males, reduzindo-os nas suas depredações, evitando innumeras desgraças, promettendo uma especie futura menos doentia, mais sadia, mais forte, mais robusta. Avançada esta proposição, que tem apparentemente uns toques ligeiros de hyperbolica, vou demonstral-a, patenteando a sua veracidade, que não deve ter passado desapercebida ao espirito dos estudiosos.

Eu não vou apreciar o valor dessas conquistas, o que seria fugir á intenção deste trabalho, nem dizer de todas as descobertas, com que o genio humano tem enriquecido, ultimamente, o campo da acção curativa dos remedios.

O meu intento é outro. Não vou repetir o que está escripto e todos conhecem. Vou apenas mostrar as consequencias que para os vindouros, para a geração que vem atraz da nossa, já beneficiada por tantas acquisições nos outros terrenos, terá o uso, o emprego de tres medicações que, certamente, vae lhes diminuir os tormentos da doença, e o que é peior, da doença que nem sempre acarretando logo a morte, atira o individuo na vala conmum da enfermidade, que é a inutilidade, que é a inaç̧ão. 
Refiro-me a tres remedios cujos effeitos a observação já consigna e já se acham affirmados, como reaes, beneficos, uteis e indispensaveis para a grandeza da raça futura. São elles - o iodeto de sodio e o neosalvarsan, em injeç̧ões endovenosas, e a emetina em injecções hypodermicas.

$\mathrm{O}$ iodeto de sodio, pelo methodo de Klemperer, em injeç̧ões endovenosas é hoje o tratamento que se está tornando classico do rheumatismo, tanto do agudo como do chronico, em todas suas variedades. A sua solução póde ser de 10 por 100, conforme manda o auctor ou de 20 por 100 , como muitos usam, eu entre elles. Faz-se uma injecção diaria de 10 centim. cubos ou 20 desta solução, e têm se observado casos de cura verdadeiramente extraordinarios, não só porque se obtem resultado certo e seguro como porque se o consegue, definitivo e permanente. Muitos clinicos usam as grandes dóses, quer dizer fazem injecção de 20 e 30 grs. de iodeto ao dia, com pequenos intervallos de 3 e 4 dias. Eu prefiro - e assim tenho feito na minha clinica - as dóses menores diariamente renovadas. São innumeros os casos de cura que tenho observado. No rheumatismo articular agudo, acompanhado de sua symptomatologia classica, o effeito dessá therapeutica é prodigioso e meu archivo se acha cheio de doentes, que se curaram radicalmente da molestia, com o uso de pequenas series dessas injeç̧ões. Nas dôres rheumaticas fugazes, tão frequentes em nossa terra, motivadas pelas mudanças abruptas de temperatura e pela humidade athmospherica constante, essas injecções são de effeito verdadeiramente surprehenrente. Fazem desapparecel-as e, si o tratamento é continuado por algum tempo, não voltam mais. No rheumatismo chronico deformante melhoram muito as condições dos doentes e si nãọ conseguem, nos casos velhos, o desapparecimento da deformasão, o que fazem nos casos jovens, alliviam bastante os soffrimentos e deixam a deformidade indolor.

Na tabes têm sido egualmente aconselhadas para combater as dôres, mesmo as fulgurantes, o que se tem conseguido com successo. Pois bem; isto é um facto já consagrado nos annaes da therapeutica, mas não é sobre elle que quero dizer duas palavras. Quero falar das consequencias beneficas, para o futuro dos doentes, do emprego dessa therapeutica. Si se consegue, como já tenho conseguido, curar em poucos dias o rheumatismo articular agudo, temos em mãos um remedio capaz de evitar as 
suas consequencias posteriores tão frequentes, tão habituaes, que são a endocardite e os seus reliquats, as lesões cardiacas orificiaes. Sendo assim, teremos as estatisticas annunciando daqui a annos a diminuição das affeções cardiacas, a diminuição dessas lesões, que são, como pregou Bouillaud, nas suas memoraveis leis, a complicação inevitavel e quasi certa do rheumatismo agudo. Estou crente que si se divulgar, por todos os clinicos, esta therapeutica, as endocardites e as lesões cardiacas terão tendencia a desapparecer da nosographia, pelo menos aquellas motivadas por essa molestia, sendo o menor numero dependente de outros factores etiologicos. Esse é o grande passo para o futuro e o que queria mostrar, chamando a attenção dos collegas para esse ponto, exagerando talvez um pouco para melhor lhes patentear o brilho desse remedio, que é, actualmente, um poderoso agente medicamentoso.

Com o neosalvarsan dá--se a mesma cousa. Aqui, porém, as consequencias se fazem vêr em futuro bem proximo, porque já se estão mostrando. Com o advento da medicação de Ehrlich está fóra de duvida que a therapeutica tem, actualmente, em mãos um poderoso meio de atacar a lues. Ha casos assignalados de cura de infecção, não de cura das manifestações, mas de cura mesmo da infecção, que se attesta com a negatividade permanente da reacção de Wassermann, após ter sido positiva. Quer dizer que se tem hoje meio seguro de cortar os males da lues, pela raiz, evitando a enorme série de perturbações que ella acarreta.

As consequencias serão certas e inevitaveis. Com o neosalvarsan os abortỏs tenderão a diminuir. Sabe-se qual a acção energica desse remedio nas mulheres gravidas e que não podiam levar a termo o producto da concepção. Quer dizer que a mortinatalidade ha de diminuir fatalmente e estrondoso resultado para a população, que se vê desfalcada, mercê da syphilis, de tanta creança que não chega a ver a luz do dia.

As estatisticas européas consignam o facto, cuja eridencia se ha de verificar mais tarde em toda parte.

Curando-se a syphilis ou mesmo que se a não cure, mas attenuando-se a sua virulencia, ha de se conseguir egualmente o desapparecimento de tantas lesões, que são a consequencia. E' assim que os aneurysmas da aorta, a insufficiencia aortica endarterial, as aortites, a tabes, a paralysia geral, as endar- 
terites vão diminuir no futuro. O facto já está sendo observado. Outróra a hemiplegia, dependente de arterite syphilitica, era muito commum nas enfermarias do hospital. Hoje, podese dizer, que constitue raridade. Isto é o que tenho observado e commigo quero crêr que os demais collegas já tenham tido a mesma impressão. O facto é significativo. Outróra os doentes tinham cephaléa, constante, persistente, duradoura e o remedio que se applicava - o mercurio - era insufficiente para impedir a irrupção do ataque hemiplegico. Hoje, com o medicamento de Ehrlich, pode-se impedil-o, com segurança.

Esta benefica influencia dessa therapeutica vale tudo e basta para attestar a sua grandeza e o que a humanidade lucrou com sua descoberta. Os clinicos no futuro encontrarão essas affeç̧̃es como raridades e poderão, então, dar testemuwho da ação bemfazeja desse remedio, que é a maior conquista therapeutica do seculo que atravessamos. Devemos empregal-a com abundancia, porque si não cura, como querem alguns auctores, presos ao chauvinismo, doutrina que em sciencia é quasi um crime, restringe os effeitos maleficos da syphilis e dará ao mundo uma raça sem a decadencia que marca a actual, em que a syphilis carimba, com seu sello, quasi toda a humanidarle.

A emetina é o remedio por excellencia da dysenteria amebiana. Os seus effeitos são quasi sempre certos e constantes. Em injeç̧ões hypodermicas corta as manifestações da amebiose intestinal. Mas, o que é mais, e é sobre o que quero accentuar, inıpede tambem o apparecimento do abcesso hepatico, que é sua complicação mais frequente.

Este facto já está consagrado. Outr'ora esses abcessos eram habituaes e nas enfermarias da Santa Casa abundavam os doentes de suppuração do figado. Hoje são raros. Quer di: :er que a emetina os impede, corta a evolução malefica do germen, que não determina mais a sua costumeira infeç̧ão.

Eis ahi o que eu queria dizer da acção altamente benefica desses tres medicamentos que vêm limpar a humanidade de tantas maculas, que no futuro existirão apenas como lembrança. E, então, a medicina terá adquirido, com direito, os fóros respeitareis de sciencia, esmagando, pelas suas conquistas, a inveja e o charlatanismo. 